\title{
USE OF DISCRIMINATORY MODELS TO VERIFY THE LIKELIHOOD OF CONTINUED ACTIVITIES FOR ENTERPRISES: CASE STUDY ON SELECT ENTERPRISES FROM THE AUTOMOTIVE INDUSTRY
}

\author{
Wojciech Lichota ${ }^{凶}$ \\ University of Rzeszów, Poland
}

\begin{abstract}
The main aim of this article is to assess the use of discriminatory models to verify the likelihood that an enterprise's activities will continue, using a sample of enterprises from the automotive industry as a case study. The suitability of 10 models will be verified by a three-point credit assessment method. As seen in the research results, discriminatory models can be used to verify an enterprise's likelihood of continuing its activity. Taking into account the received values for discriminatory functions and banking methods over four years, a convergence of indications was demonstrated. In the vast majority of cases, the increase or decrease in the value of the functions was reflected in a corresponding change in the value of banking methods. Based on the conducted research, it should be stated that the most characteristic variables influencing the values of the discriminant function in the automotive industry concerned debt and profitability.
\end{abstract}

Key words: discriminant analysis, banking methods of assessing creditworthiness, financial condition of the enterprise, early warning models

JEL codes: G17, G32

\section{INTRODUCTION}

Discriminant analysis models were developed to detect an enterprise's possible risk of bankruptcy. The first works in this area were carried out in the 1960s, when in the United States, Altman developed models enabling quick detection of threats to the functioning of enterprises [Altman 1968]. So far, a lot of research has been conducted on the financial condition of the automotive industry globally. It is worth mentioning here some specific works:

- The financial condition of the auto industry in India in 2003-2010 [Ray 2011];

- Re-evaluation of the bankruptcy reorganisation of Chrysler and General Motors [Adler 2010];
- Bankruptcy risk forecasting for the automotive parts manufacturing industry [Park and Han 2013];

- The financial condition of companies included in the BSE-GREENEX stock index in India [Swalih and Vinod 2017];

- The condition of selected Indian automotive companies [Kannan and Monisha 2016];

- Restructuring of bankruptcies of Chrysler and General Motors [Brubaker and Tabb 2010].

Correct assessment of a company's financial condition is of great importance for both internal stakeholders, i.e. owners and executives, as well as for external entities, i.e. financial institutions, competition, and cooperating entities. The aim of this article is to assess the use of discriminatory models to verify the likelihood 
of an enterprise's continued business activities (case study: select automotive companies), and to determine which variables from accepted models have the greatest impact on the reduction of activities, and which increase the value of the function. In addition, the financial condition of the companies will be verified by a three-point credit worthiness evaluation method. The research sample will consist of 10 enterprises operating in the automotive industry on the Polish market in the years 2013-2017'. The sample consists of the companies with the largest total assets selected from the Emerging Markets Information Service (EMIS) database. Ten discriminatory models were verified, drawn from attempts on 35 discriminatory models, with the goal to present one primary model then tested by the author on a sample of manufacturing companies from several sectors. The research period is four years.

Taking into account the title of the article and the fact that the enterprises continue to operate, the following hypothesis was made: "The greatest potential for prediction with the correct classification of entities is found from variables concerning profitability".

\section{THEORETICAL ASPECTS OF DISCRIMINANT MODELS AND CREDIT WORTHINESS ASSESSMENT METHODS}

Determining the value of the discriminant function leads to comparison with specific limit values, which allows the proper classification of the examined object to the group of objects at risk of bankruptcy or to the group with a stable financial condition [Janik 2018], moreover, these models are transparent and the obtained results are easy to interpret [Piróg 2016].

The linear discriminant function has the following form:

$$
Z=a_{0}+a_{1} X_{1}+a_{2} X_{2}+\ldots+a_{n} X_{n}
$$

where:

$Z$ - value of the discriminant function,

$X_{i}$ for $i=1,2, \ldots, n-$ explanatory variables (financial indicators),

$a_{i}$ for $i=1,2, \ldots, n$ - coefficients of the discriminant function,

$a_{0}-$ constant.

The result is interpreted on the basis of a comparison of the calculated $Z$ value of the discriminant function with the limit value established by the author of the model. The classification of entities to separate groups is based on the value of $Z$ [Zielińska-Sitkiewicz 2012].

The following models were used to assess the financial condition of enterprises ${ }^{2}$ :

1. Model of E. Mączyńska [Mączyńska 1994].

2. Model INE PAN G [Mączyńska and Zawadzki 2006].

3. Model 1 of D. Appenzeller and K. Szarzec [Appenzeller and Szarzec 2004].

4. The "Poznań" model [Hamrol et al. 2004].

5. Model 1 of D. Hadasik [Hadasik 1998].

6. Model of T. Korol [Korol 2010].

7. Model of T. Maślanka a year before [Maślanka 2008].

8. Model of M. Tymoszuk [Tymoszuk 2013].

9. Model of B. Prusak [Prusak 2005].

10. Model 2 of J. Gajdka and D. Stos [Gajdka and Stos 1996].

The models selected for the assessment were tested by the authors on a sample of production companies operating on the Polish market. Models that apply only to the trade, construction and services sectors were excluded from the drawing. The models are different because in their construction from four to six different indicators of financial analysis were used. Some models do not include liquidity, e.g. E. Mączyńska

\footnotetext{
${ }^{1}$ The financial statements cover the following years: 2013-2016 (three companies), 2014-2017 (six companies), 2015-2017 (one company). Selecting a larger sample of enterprises would mean that the data would cover the years 2010-2012 and therefore would be too distant.

${ }^{2}$ Due to the specific length of the article and wide scope of available literature, some discriminant function designs and constructions of individual indicators are presented. The breadth of bank credit instructions also makes it impossible to present them.
} 
Lichota, W. (2020). Use of discriminatory models to verify the likelihood of continued activities for enterprises: case study on select enterprises from the automotive industry. Acta Sci. Pol. Oeconomia 19 (4), 95-102, DOI: 10.22630/ASPE.2020.19.4.45

and D. Hadasik, or activities, e.g. the "Poznan" model. However, some models mainly include activity indicators in their design, e.g. the model by D. Hadasik or profitability indicators, e.g. the models of Poznań, B. Prusak, J. Gajdka and D. Stos.

The advantage of one group of indicators over other groups or the lack of some categories of indicators affects the obtained function values. Therefore, 10 models were selected to ensure the greatest possible variety of the research sample. In most models, the cut-off point is " 0 ", therefore, it may be difficult to interpret when the obtained results are almost that value.

The main aim of modern bank information systems is to reduce risk, especially that which is undertaken in granting credit, because the most profitable bank assets in Poland are broadly understood to be the credit they have issued. Proper use of acquired information about customers is a fundamental premise of success, reflected in an increase in the effectiveness of a bank's operations, the measurable expression of which is the increase in profit. Therefore, the assessment of creditworthiness by the bank is so important [Szustak 2014]. Estimating a company's creditworthiness on the basis of banking methods is carried out by analysing the results obtained in individual years of operation. Due to the diversity of investment projects implemented by enterprises and often financed by banks, both banks and enterprises must use different methods of assessing the profitability of investment projects, which usually require both their own and external financing [Różański 2001].

The scoring method of banking risk assessment belongs to the group of simple, but quite common methods of synthetic assessment of a company's financial condition. It allows, without knowing the discriminant function, to reduce the assessment of 10 financial indicators to the "common denominator". In the discussed method, some number of points are assigned to a given range of indicators, on a scale from one (the highest score) to five (the lowest score). This method does not take into account the criterion of the industry specificity of the surveyed company.

In the methods of assessing financial condition, the borrowers and some banks modified the assumptions of the scoring method for assessing banking risk as discussed above. While in the case of the assessment of profitability, financial liquidity and debt indicators, they use these assumptions almost unchanged, in the case of the analysed activity indicators, a certain number of points is awarded depending on the shaping of a given indicator against the average for the industry [Kitowski 2012].

Three methods used by the largest banks in Poland will be used to verify the financial condition of enterprises. Due to the fact that banking procedures include both quantitative and qualitative assessment, in order to obtain full comparability of all the methods presented, this article does not attempt to perform a qualitative assessment. The article takes into account three methods used by banks in Poland.

- In Bank A, when the total score of a quantitative assessment is from 10 to 15 , the financial condition is very good. But the more points, the worse the condition. When the total score of a quantitative assessment is from 56 to 59 , the financial condition is very poor.

- In Bank B, it is possible to obtain a total of 45 points, of which a maximum of 30 points is allocated to the quantitative assessment.

- In Bank C, it is possible to obtain a total of 80 points, of which a maximum of 45 points is for the quantitative assessment.

According to the research conducted so far on the automotive industry:

- The capital structure of large- and medium-sized enterprises in the automotive industry in the Czech Republic was influenced by three dependent and five independent variables. The dependent variables are: total debt, long-term debt, and short-term debt ratios. The independent variables are: size, tangibility, profitability, liquidity and growth. Total debt was found to be positively related to tangibility and profitability and negatively to size and liquidity. Long-term debt is positively related to size and tangibility and negatively to profitability and liquidity. Short-term debt is positively related to tangibility and profitability and negatively to size and liquidity. Growth has little effect on all three debt measures. The results of the study show that the nature of the relationship largely depends on the choice of financial leverage. Larger firms prefer equity financing and tend to use long-term rather 
than short-term debt. Firms with more assets tend to finance debt. More liquid companies prefer equity financing. More profitable companies are willing to raise equity and short-term debt [Pinková 2012].

- Enterprises decide on their capital structure on an ad hoc basis; they are primarily driven by the desire to maintain financial liquidity. The Polish economy is dominated by short-term liabilities in the structure of liabilities, the cost of which is high and the maturity date is short. The structure of capital is determined by the dominant factors: asset structure, current liquidity, profitability and size of the enterprise. Foreign capital is used only when the entity's own funds turn out to be insufficient to cover the financial needs. Enterprises are afraid of the costs of bankruptcy; they minimize the level of financial risk by limiting foreign capital [Wilimowska and Wilimowski 2010].

- Multiplier effects strengthen the rationale to rescue the automotive industry: stimulating vehicle demand is seen as an effective way to stimulate aggregate demand; stimulating vehicle demand has environmental benefits; helping car manufacturers help solve credit problems [Sturgeon and Van Biesebroeck 2009].

\section{RESULTS OF THE ASSESSMENT OF THE FINANCIAL CONDITION OF COMPANIES AND DISCUSSION}

Table 1 presents the results of individual discriminant and scoring models of banking methods presented in the previous chapter.

The main aim of the article is to assess the possibility of using discriminant models to verify the likelihood of continuation of business operations on the example of a sample of enterprises in the automotive industry and to determine which variables of the adopted models had the greatest impact on the decrease and increase in the value of the function. Due to the fact that the companies on which the calculations were made are present on the market, discriminatory models should not indicate the risk of their bankruptcy or it should occur sporadically. Also, the number of points obtained on the basis of banking methods should not indicate a lack of financial condition, and therefore should be at least $50 \%$ of the points that can be obtained in the quantitative assessment.

Based on the results presented in Table 1, it should be noted that almost none of the enterprises are threatened with bankruptcy. The exception is enterprise 4, whose results in 2016 were not optimistic and most of the methods indicated the risk of bankruptcy or a deteriorating situation. Due to the fact that all enterprises included in the research sample operated in the years that followed, it should be assumed that the indications of bankruptcy risk were incorrect. The correctness of indications of individual models in the four-year period, i.e. qualifying enterprises to the group with a safe financial condition, are shown in Table 2.

A very low number of points was awarded by bank B and bank C to enterprise 2 in 2015-2016 and enterprise 4 in 2014-2017. In contrast, the best scores were received by enterprises 3,6 and 10. Taking into account the indications of each model, we note that the models of E. Mączyńska and INE PAN G do not indicate any risk of bankruptcy of the enterprises and the value of these functions are changing and almost converge with other indication banking models and methods. Other models subject to verification, which on the basis of the conducted research indicated a single and double risk of bankruptcy, are the "Poznań" model, as well as the D. Appenzeller and K. Szarzec models. These models indicated a risk of bankruptcy of company No. 2 in 2016, just like the other five models. A weaker situation was also indicated by bank B and bank $\mathrm{C}$, which allocated respectively only $34 \%$ and $29 \%$ of the total points of quantification.

The models of D. Hadasik and T. Korol contain three indications of the risk of bankruptcy. The threat is also demonstrated by the methods of bank B and bank $\mathrm{C}$ and concerns enterprises 2 and 4 .

The remaining discriminatory models indicated the risk of bankruptcy from five to 17 times. In these cases, it can also be observed that in those years where discriminatory models indicated the risk of bankruptcy of the enterprises, also banking methods allowed to adopt a similar position.

It is important to note that there are some exceptions. In the case of enterprise 10, banking methods indicate a good financial condition, however, the models 
Table 1. Results of individual discriminant models for a selected sample of enterprises in four consecutive years

\begin{tabular}{|c|c|c|c|c|c|c|c|c|c|c|c|c|c|c|}
\hline 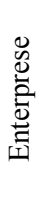 & 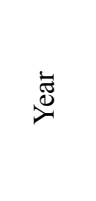 & 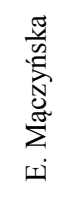 & 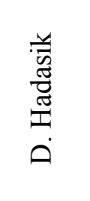 & $\begin{array}{l}0 \\
Z \\
Z \\
\vdots \\
\text { 岌 } \\
\text { Z }\end{array}$ & $\begin{array}{l}\overline{0} \\
\stackrel{\Xi}{\Xi} \\
\text { İ工 } \\
\dot{\Sigma}\end{array}$ & 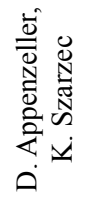 & 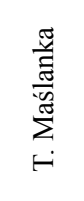 & 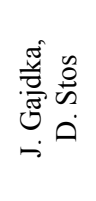 & 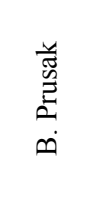 & 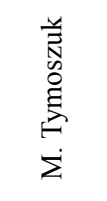 & $\begin{array}{l}\overrightarrow{0} \\
\dot{0} \\
\stackrel{1}{1} \\
\dot{H}\end{array}$ & 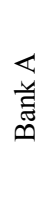 & 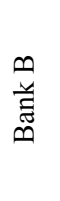 & $\begin{array}{l}u \\
\ddot{\Xi} \\
\ddot{\Xi}\end{array}$ \\
\hline \multirow{4}{*}{1} & 2014 & 1.70 & 1.70 & 3.26 & 2.93 & 0.56 & 2.25 & 0.56 & 0.12 & 2.98 & -1.88 & 28 & 19 & 35 \\
\hline & 2015 & 1.87 & 1.80 & 3.39 & 3.46 & 0.45 & 2.40 & 0.58 & 0.11 & 3.13 & 1.95 & 26 & 21 & 35 \\
\hline & 2016 & 1.43 & 1.80 & 3.16 & 3.37 & 0.33 & 2.15 & 0.61 & -0.10 & 3.04 & 1.65 & 26 & 22 & 32 \\
\hline & 2017 & 2.05 & 1.73 & 3.59 & 3.61 & 0.49 & 2.46 & 0.50 & 0.11 & 2.96 & 1.95 & 28 & 21 & 37 \\
\hline \multirow{4}{*}{2} & 2014 & 2.31 & 1.72 & 3.16 & 2.50 & 1.06 & 2.06 & 0.64 & 0.34 & 3.14 & 2.87 & 26 & 18 & 29 \\
\hline & 2015 & 1.18 & 1.24 & 1.45 & 0.58 & -0.01 & 0.50 & 0.87 & -0.41 & 0.27 & -0.03 & 33 & 11 & 17 \\
\hline & 2016 & 0.67 & 0.88 & 0.47 & -0.11 & -0.26 & -0.48 & 1.04 & -0.63 & -24.75 & 0.90 & 28 & 10 & 13 \\
\hline & 2017 & 1.75 & 1.20 & 2.02 & 1.35 & 0.18 & 0.93 & 0.79 & 0.07 & 0.17 & -1.69 & 30 & 13 & 20 \\
\hline \multirow{4}{*}{3} & 2014 & 2.34 & 1.86 & 5.86 & 5.70 & 1.59 & 4.33 & 0.53 & 0.77 & 4.62 & -4.48 & 22 & 25 & 36 \\
\hline & 2015 & 2.68 & 1.92 & 6.17 & 7.12 & 1.78 & 4.28 & 0.56 & 1.09 & 4.92 & -5.36 & 22 & 26 & 40 \\
\hline & 2016 & 3.31 & 1.91 & 6.73 & 8.07 & 1.82 & 4.40 & 0.42 & 1.30 & 5.20 & 5.67 & 21 & 26 & 41 \\
\hline & 2017 & 2.51 & 1.78 & 5.34 & 6.31 & 1.66 & 3.49 & 0.52 & 0.87 & 4.53 & -4.69 & 24 & 26 & 37 \\
\hline \multirow{4}{*}{4} & 2014 & 0.77 & -0.04 & 0.40 & 0.70 & 0.43 & -0.21 & 1.00 & -0.34 & -5.44 & -0.07 & 40 & 11 & 17 \\
\hline & 2015 & 0.53 & 0.02 & 0.25 & 0.29 & 0.19 & -0.35 & 1.06 & -0.39 & -7.07 & 0.29 & 44 & 8 & 12 \\
\hline & 2016 & 0.33 & -0.01 & 0.02 & 0.29 & 0.05 & -0.64 & 1.07 & -0.65 & -11.88 & 0.57 & 46 & 11 & 12 \\
\hline & 2017 & 0.48 & -0.17 & 0.50 & 2.40 & 1.28 & -0.11 & 1.07 & -0.03 & -7.60 & -1.14 & 41 & 12 & 20 \\
\hline \multirow{4}{*}{5} & 2014 & 3.72 & 1.87 & 5.47 & 4.22 & 2.10 & 3.70 & 0.24 & 0.92 & 4.11 & -4.58 & 22 & 23 & 38 \\
\hline & 2015 & 5.16 & 2.04 & 7.35 & 5.22 & 2.61 & 4.90 & -0.08 & 1.50 & 5.20 & -6.32 & 20 & 26 & 42 \\
\hline & 2016 & 4.25 & 1.99 & 5.69 & 4.63 & 2.24 & 3.51 & 0.01 & 1.26 & 4.78 & -5.15 & 21 & 25 & 42 \\
\hline & 2017 & 4.29 & 1.83 & 4.95 & 4.16 & 2.08 & 2.78 & -0.02 & 0.84 & 4.27 & -4.10 & 22 & 22 & 39 \\
\hline \multirow{4}{*}{6} & 2014 & 1.28 & 1.53 & 2.14 & 2.55 & 0.49 & 1.42 & 0.78 & 0.10 & 1.20 & -1.66 & 24 & 20 & 33 \\
\hline & 2015 & 1.66 & 1.69 & 2.64 & 3.18 & 0.67 & 1.78 & 0.70 & 0.30 & 2.39 & -2.50 & 22 & 21 & 34 \\
\hline & 2016 & 0.62 & 1.55 & 1.62 & 2.54 & 0.42 & 1.12 & 0.95 & -0.05 & 0.44 & -1.54 & 28 & 19 & 27 \\
\hline & 2017 & 1.44 & 1.58 & 2.09 & 2.67 & 0.53 & 1.31 & 0.80 & -0.05 & 1.54 & -1.87 & 25 & 20 & 33 \\
\hline \multirow{4}{*}{7} & 2013 & 5.25 & 1.09 & 5.84 & 3.87 & 2.60 & 4.72 & -0.11 & 1.89 & 1.31 & -5.41 & 27 & 21 & 39 \\
\hline & 2014 & 3.69 & 1.10 & 3.93 & 2.88 & 0.82 & 2.54 & 0.23 & 0.83 & 1.20 & 2.37 & 31 & 19 & 34 \\
\hline & 2015 & 3.64 & 1.01 & 3.76 & 2.85 & 1.03 & 2.43 & 0.27 & 0.97 & 0.70 & -2.53 & 32 & 17 & 30 \\
\hline & 2016 & 4.39 & 1.12 & 4.78 & 3.22 & 1.20 & 3.09 & 0.05 & 1.30 & 1.64 & 3.35 & 31 & 20 & 34 \\
\hline \multirow{4}{*}{8} & 2013 & 2.22 & 1.52 & 3.48 & 5.06 & 1.04 & 2.05 & 0.44 & 0.30 & 2.28 & 2.27 & 28 & 23 & 34 \\
\hline & 2014 & 2.07 & 1.49 & 3.14 & 3.50 & 0.64 & 1.96 & 0.47 & 0.06 & 2.26 & -1.57 & 26 & 20 & 37 \\
\hline & 2015 & 1.18 & 1.15 & 2.84 & 4.30 & 0.55 & 1.74 & 0.70 & -0.08 & 1.97 & -1.82 & 29 & 21 & 31 \\
\hline & 2016 & 0.93 & 1.54 & 1.52 & 2.43 & 0.40 & 0.86 & 0.80 & -0.23 & 0.00 & -0.87 & 35 & 18 & 32 \\
\hline \multirow{4}{*}{9} & 2013 & 1.72 & 1.04 & 1.85 & 1.00 & 0.58 & 0.90 & 0.90 & 0.25 & -1.54 & -1.53 & 28 & 21 & 37 \\
\hline & 2014 & 1.85 & 1.02 & 2.07 & 1.16 & 0.64 & 0.79 & 0.57 & 0.07 & -1.38 & $-1,01$ & 28 & 19 & 35 \\
\hline & 2015 & 0.81 & 1.00 & 0.97 & 0.53 & 0.36 & 0.29 & 1.07 & -0.37 & -2.96 & -0.22 & 26 & 21 & 35 \\
\hline & 2016 & 1.35 & 1.02 & 1.29 & 0.99 & 0.52 & 0.55 & 0.89 & -0.09 & -2.20 & -0.53 & 26 & 22 & 32 \\
\hline \multirow{3}{*}{10} & $2015^{a}$ & 1.85 & 2.10 & 4.04 & 6.15 & 3.57 & 2.93 & 0.79 & 1.15 & 3.74 & -5.38 & 22 & 24 & 31 \\
\hline & 2016 & 2.18 & 2.14 & 4.38 & 6.67 & 3.96 & 3.17 & 0.82 & 1.62 & 4.09 & -6.98 & 20 & 26 & 32 \\
\hline & 2017 & 1.28 & 2.02 & 3.55 & 5.56 & 3.21 & 2.86 & 0.95 & 1.23 & 3.12 & -5.60 & 21 & 24 & 30 \\
\hline
\end{tabular}

a Due to the lack of data, the calculations were made for the period 2015-2017.

The research sample consisted of: 1 - Firma Oponiarska Dębica S.A.; 2 - Volkswagen Poznań Sp. z o.o.; 3 - Toyota Motor Manufacturing Poland Sp. z o.o.; 4 - Solaris Bus Coach S.A.; 5 - Sitech Sp. z o.o.; 6 - Trw Polska Sp. z o.o.; 7 - Hutchinson Poland Sp. z o.o.; 8 - Nexteer Automotive Poland Sp. z o.o.; 9 - Faurecia Wałbrzych S.A.; 10 - MAN Trucks Sp. z o.o.

Source: Author's own study. 
Lichota, W. (2020). Use of discriminatory models to verify the likelihood of continued activities for enterprises: case study on select enterprises from the automotive industry. Acta Sci. Pol. Oeconomia 19 (4), 95-102, DOI: 10.22630/ASPE.2020.19.4.45

Table 2. Correctness of indications of individual models over a four-year period

\begin{tabular}{ll}
\hline Model (author) & $\begin{array}{c}\text { Forecast accuracy } \\
(\%)\end{array}$ \\
\hline E. Mączyńska & 100 \\
\hline INE PAN G (E. Mączyńska, M. Zawadzki) & 100 \\
\hline D. Appenzeller and K. Szarzec (1) & 97 \\
\hline "Poznański” (M. Hamrol, B. Czajka, M. Piechocki) & 97 \\
\hline D. Hadasik & 92 \\
\hline T. Korol & 92 \\
\hline T. Maślanka & 87 \\
\hline M. Tymoszuk & 77 \\
\hline B. Prusak & 67 \\
\hline J. Gajdka and D. Stos (2) & 56 \\
\hline
\end{tabular}

Source: Author's own study.

of J. Gajdka and D. Stos indicate the risk of bankruptcy, which additionally increases in the following years.

Therefore it must be concluded that the assessment of the financial condition of a company should be done for at least a few models of discrimination, so as to exclude their possible maladjustment to the subject under study.

As a result of the research, it should be noted that the following variables, indicated in Table 3 , had the greatest impact on the value of individual functions:

Table 3. Variables in a given model that had the greatest impact on its value

\begin{tabular}{lcc}
\hline Model (author) & Variables & \\
\hline E. Mączyńska & (profit before tax + amortisation) / liabilities & profit before tax / assets \\
\hline $\begin{array}{l}\text { INE PAN G } \\
\text { (E. Mączyńska, M. Zawadzki) }\end{array}$ & equity/assets & (net profit + amortisation) / liabilities \\
\hline D. Appenzeller and K. Szarzec (1) & current ratio & quick ratio \\
\hline "Poznański” & quick ratio & permanent capital / assets \\
(M. Hamrol, B. Czajka, M. Piechocki) & liabilities/assets & stock · 365 / income \\
\hline D. Hadasik & profit on sale / assets & operating costs / short-term liabilities \\
\hline T. Korol & equity / assets & (operating profit + amortisation) / \\
\hline T. Maślanka & equity / assets & EBIT / assets \\
\hline M. Tymoszuk & profit on sale / assets & operating costs / short-term liabilities \\
\hline B. Prusak (3) & liabilities / assets & net profit / assets
\end{tabular}

Source: Author's own study. 


\section{CONCLUSIONS}

Evaluating the potential for discriminatory use of models to verify the likelihood of continued business activities for a sample of automotive enterprises, and comparing the results with those obtained using the bank methods, combined a variety of methods resulting from scientific research and practice. The aim of the study was achieved and it was shown that discriminatory models can be used to verify the likelihood of continued activities of enterprises from the automotive industry. However, it was shown that debt ratios had the greatest impact on the decrease and increase in the value of the function. This means that the hypothesis that variables related to profitability would have the greatest potential for prediction with the correct classification of entities, was not proven.

Based on the conducted research, it should be stated that:

- The most characteristic variables influencing the values of the discriminant function in the automotive industry concerned debt and profitability.

- There is a view in the literature that:

- the dependent variables are total debt, long-term debt and short-term debt ratios but the independent variables are size, tangibility, profitability, liquidity and growth [Pinková 2012];

- enterprises decide on their capital structure ad hoc, they primarily want to remain financial liquidity [Wilimowska and Wilimowski 2010];

- if the results obtained with the use of banking methods proved the improving financial situation of enterprises, then the values of discriminatory functions increased (or decreased - the model of J. Gajdka and D. Stos);

- in order to reduce the risk of incorrect diagnosis of financial condition, at least several models should be used;

- $100 \%$ efficiency the discriminatory models of E. Mączyńska and INE PAN G;

- the lowest efficiency was shown by the discriminatory models of J. Gajdka and D. Stos (56\%), meaning they did not work for the evaluation of companies in the automotive industry.
Taking into account the above, it should be remembered that the conducted research contained certain limitations, i.e. a small number of examined entities and their deliberate selection in terms of the value of assets. Moreover, there was no bankrupt enterprise in the research group.

The issue of the financial condition of enterprises is still relevant. Therefore, this article can be used as a starting point for further research.

\section{REFERENCES}

Adler, B.E. (2010). A reassessment of bankruptcy reorganization after Chrysler and General Motors. The American Bankruptcy Institute Law Review, 18, 305-318.

Altman, E.I. (1968). Financial Ratios, Discriminant Analysis and the Prediction of Corporate Bankruptcy. The Journal of Finance, 4, 589-609.

Appenzeller, D., Szarzec, K. (2004). Prognozowanie zagrożenia upadłością polskich spółek publicznych. Rynek Terminowy, 1, 120-128.

Brubaker, R., Tabb, C.J. (2010). Bankruptcy Reorganizations and the Troubling Legacy of Chrysler and GM. Jurnalul de Studii Juridice, 5, 1375-1410.

Gajdka, J., Stos, D. (1996). Wykorzystanie analizy dyskryminacyjnej do badania podatności przedsiębiorstwa na bankructwo. [In:] J. Duraj (Ed.), Przedsiębiorstwo na rynku kapitałowym. PWE, Łódź, 138-148.

Hadasik, D. (1998). Upadłość przedsiębiorstw w Polsce i metody jej prognozowania. Zeszyty Naukowe Akademii Ekonomicznej w Poznaniu. Seria II. Prace Habilitacyjne 153 .

Hamrol, M., Czajka, B., Piechocki, M. (2004). Upadłość przedsiębiorstwa - model analizy dyskryminacyjnej. Przegląd Organizacji, 6, 35-39.

Janik, K. (2018). Bankructwo czy stabilność rynkowa - Analiza wybranych polskich modeli dyskryminacyjnych na przykładzie spółki Alma Market S.A. Zeszyty Naukowe Politechniki Częstochowskiej. Zarządzanie, 29, 235-248.

Kannan, V., Monisha, V. (2016). Financial Soundness of Selected Indian Automobile Companies using Altman Z Score Model. International Journal of Advanced Scientific Research \& Development, 3 (1), 89-95.

Kitowski, J. (2012). Sposoby ujmowania kryterium specyfiki branżowej w metodach oceny kondycji finansowej przedsiębiorstwa. Prace i Materiały Wydziału Zarządzania Uniwersytetu Gdańskiego Zarządzanie i Finanse, Gdańsk, 4, 271-272. 
Lichota, W. (2020). Use of discriminatory models to verify the likelihood of continued activities for enterprises: case study on select enterprises from the automotive industry. Acta Sci. Pol. Oeconomia 19 (4), 95-102, DOI: 10.22630/ASPE.2020.19.4.45

Korol, T. (2010). Systemy ostrzegania przedsiębiorstw przed ryzykiem upadłości. Oficyna Wolters Kluwer, Warszawa.

Mączyńska, E. (1994). Ocena kondycji przedsiębiorstwa (Uproszczone metody). Życie Gospodarcze, 38, 42-45.

Mączyńska, E., Zawadzki, M. (2006). Dyskryminacyjne modele predykcji przedsiębiorstw. Ekonomista, 2, 205-235.

Maślanka, T. (2008). Przepływy pieniężne w zarządzaniu finansami przedsiębiorstw. Wydawnictwo C.H. Beck, Warszawa.

Park, K.Y., Han, H.S. (2013). Bankruptcy Risk Level Forecasting Research for Automotive Parts Manufacturing Industry. Journal of Information Technology Applications and Management, 20 (4), 221-231.

Pinková, P. (2012). Determinants of capital structure: evidence from the Czech automotive industry. Acta Universitatis Agriculturae et Silviculturae Mendelianae Brunensis, 60 (7), 217-224.

Piróg, A. (2016). Aplikacja modeli dyskryminacyjnych w ocenie kontynuacji działalności przedsiębiorstw. Studia Ekonomiczne. Zeszyty Naukowe Uniwersytetu Ekonomicznego w Katowicach, 284, 187-199.

Prusak, B. (2005). Nowoczesne metody prognozowania zagrożenia finansowego przedsiębiorstw. Difin, Warszawa.

Ray, S. (2011). Assessing corporate financial distress in automobile industry of India: An application of Altman's model. Research Journal of Finance and Accounting, 2 (3), 155-163.

Różański, J. (2001). Ewolucja metod bankowej oceny sytuacji ekonomiczno-finansowej przedsiębiorstwa w no- woczesnej gospodarce rynkowej. Przegląd Organizacji, $10,31-34$.

Sturgeon, T.J., Van Biesebroeck, J. (2010). Crisis and protection in the automotive industry: a global value chain perspective. World Bank Policy Research Working Paper 5330, https://doi.org/10.1596/1813-9450-5060

Swalih, M.M., Vinod, M.S. (2017). Application of Altman Z Score on BSE-Greenex Companies. Journal of Applied Management and Investments, 6 (3), 205-215.

Szustak, G. (2014). Informacja o kredytobiorcy - zasadnicza przesłanka bezpieczeństwa banku. Studia Ekonomiczne, 171, 65-83.

Tymoszuk, M. (2013). Skuteczność modeli prognozowania upadłości przedsiębiorstw a upływ czasu - porównanie popularnych polskich modeli wielowymiarowej analizy dyskryminacyjnej $\mathrm{z}$ modelem zbudowanym przez autorkę. [In:] A. Adamska, E. Mączyńska (Eds.), Upadłości, bankructwa i naprawa przedsiębiorstw. Wybrane zagadnienia. Oficyna Wydawnicza SGH, Warszawa, 193-210.

Wilimowska, Z., Wilimowski, M. (2010). Wpływ czynników mikroekonomicznych na zarządzanie strukturą kapitałową polskich przedsiębiorstw. [In:] R. Knosala (Ed.), Komputerowo zintegrowane zarządzanie. Oficyna Wydawnicza Polskiego Towarzystwa Zarządzania Produkcją, Opole, 639-640.

Zielińska-Sitkiewicz, M. (2012). Zastosowanie metod wielowymiarowej analizy dyskryminacyjnej do oceny kondycji firm deweloperskich. Metody Ilościowe w Badaniach Ekonomicznych, 13 (3), 289-290.

\section{WYKORZYSTANIE MODELI DYSKRYMINACYJNYCH DO WERYFIKACJI PRAWDOPODOBIEŃSTWA KONTYNUACJI DZIAŁALNOŚCI PRZEDSIĘBIORSTW NA PRZYKŁADZIE PRÓBY PRZEDSIĘBIORSTW Z BRANŻY MOTORYZACYJNEJ}

\section{STRESZCZENIE}

Celem niniejszego artykułu jest ocena możliwości wykorzystania modeli dyskryminacyjnych do weryfikacji prawdopodobieństwa kontynuacji działalności przedsiębiorstw na przykładzie próby przedsiębiorstw z branży motoryzacyjnej. Ocena 10 modeli została zweryfikowana za pomocą trzypunktowych metod oceny zdolności kredytowej. Jak wynika z przeprowadzonych badań, modele dyskryminacyjne mogą zostać wykorzystane do weryfikacji prawdopodobieństwa kontynuacji działalności przedsiębiorstw. Biorąc pod uwagę otrzymane wartości funkcji dyskryminacyjnych i metod bankowych, na przestrzeni czterech lat uwidoczniona została zbieżność wskazań. W zdecydowanej większości przypadków wzrost lub spadek wartości modeli znajdował odzwierciedlenie w odpowiedniej zmianie wartości metod bankowych. Na podstawie przeprowadzonych badań należy stwierdzić, że najbardziej charakterystyczne zmienne wpływające na wartość funkcji dyskryminacyjnych w branży motoryzacyjnej dotyczyły zadłużenia i rentowności.

Słowa kluczowe: analiza dyskryminacyjna, bankowe metody oceny zdolności kredytowej, kondycja finansowa przedsiębiorstwa, modele wczesnego ostrzegania 